\title{
Sellar Germ Cell Tumor
}

National Cancer Institute

\section{Source}

National Cancer Institute. Sellar Germ Cell Tumor. NCI Thesaurus. Code C155801.

A germ cell tumor that arises from or adjacent to the sellar region. 